\title{
Searching for the Best Way of Integration. Migrant Women in Europe
}

\begin{abstract}
Nowadays, the significance of women in the international movement of migrants is important both from a quantitative and qualitative point of view. Many migrant women move to other countries either on their own or to join their husbands or other family members. The number of migrant women is also increasing in Europe. For this reason, focusing on the phenomenon of gender-based migration has become an important research element and affects many areas. The mass migration of women from highly diverse cultural backgrounds to European countries draws particular attention to the problems of integrating these women in host countries. However, most European countries lack integration policies that take into account the real needs of migrant women. Given that women account for almost half of all migrants, data on migration should be gender-sensitive and state policies must take into account how gender actually shapes the different needs of migrants. Also, since migrant women/ refugees who come to European countries constitute a heterogeneous group in many respects, this heterogeneity should be taken into account in integration processes. In this article, two issues have been taken into account as research questions: 1 , are immigrant/refugee women treated the same as immigrant/refugee men? and 2 , is gender taken into account in the integration policies of European countries? To study the issues presented in the article, a review of the available literature was used, as well as data available on the websites of the OECD and the European Commission.
\end{abstract}

Keywords: Migration, Integration, Immigrants, Migrants, Women, Europe

^ Joanna Radowicz - Kielce University of Technology, e-mail: joannaaleksandra@wp.pl, ORCID: 0000-0002-7045-8952. 


\section{Introduction}

Migration is nowadays a very common, but also multi-dimensional, phenomenon. Migration processes may have various causes and effects, therefore the issue of migration is becoming a very important phenomenon for specialists in numerous scientific fields. The mass nature of migration observed today brings with it unprecedented results in many spheres of social life, both in the host and origin country. The phenomenon of migration in the era of globalisation generates significant social changes. On the one hand, it influences their development, and on the other, it presents them with new challenges. Migration gives a chance to improve living conditions and equalise the standard of living. It often, however, results in the loss of contact with relatives, as well as a feeling of alienation in the host country. ${ }^{1}$

The immigrant has to adapt to a new place where a different cultural code is often used, incomprehensible and which hinders proper communication. The mere knowing of the lingua franca which enables efficient functioning in a new environment may turn out to be insufficient, as different cultural principles of a host state may be incomprehensible to the immigrant and even contrary to their system of values. Moreover, ethnically and culturally "foreign" people are very often perceived by the society through the prism of stereotypes, and thus are exposed to prejudice and even discrimination. ${ }^{2}$

There are various reasons why people leave their home country. The main motivations include:

- a willingness to find a better job and prospects for life,

- the search for new professional and private experiences,

- the need to leave the home country. ${ }^{3}$

There is a continuous increase in international migration. Currently, it is estimated that there are almost 272 million migrants worldwide, which is $3.5 \%$ of the world's population. ${ }^{4}$

More than $40 \%$ of all international migrants in the world in 2019 (112 million) were born in Asia, mainly in India (the largest country of origin), China, and South Asian countries such as Bangladesh, Pakistan, and Afghanistan. ${ }^{5}$

1 M. Gacek, Strategie migracyjne Polaków po 2004 roku. Przypadek Szkocji, „Pogranicze. Polish Borderlands Studies”, no. 1/2013, p. 107.

${ }^{2}$ I. Koryś, Kobiety migrantki: warunki udanej integracji, Warsaw 2009, p. 1.

${ }^{3}$ M. Gacek, op.cit., p. 107.

4 World Migration Report 2020, p. 2, https:/www.un.org/sites/un2.un.org/files/ wmr 2020.pdf (access 11.11.2020).

5 Ibidem, p. 26. 
More than 82 million international migrants lived in Europe in 2019, which is an increase of almost 10 percent since 2015 (there were 75 million migrants at that time). From 2015 to 2019, the number of non-European migrants in Europe also increased from over 35 million to around 38 million. ${ }^{6}$

In 1990, roughly the same number of Europeans lived outside Europe as there were non-Europeans in Europe. However, contrary to the increase in migration to Europe, the number of Europeans living outside Europe has fallen in most cases in the last 30 years and has returned to its 1990 level in recent years. In 2019, European-born migrants living outside the continent lived mainly in North America ( 7.4 million). There was also a gradual increase in the number of European migrants in Asia and Oceania in 2010-2019.7

The vast majority of people migrate abroad for reasons including work, family reunification, or education. There is also a group of people who leave their homes as a result of conflicts, persecution on various grounds, and/or catastrophes. This group often needs help and support the most. ${ }^{8}$

Where large-scale migration takes place, racism and xenophobia become serious problems. Indeed, anti-immigration sentiments are increasing in many countries. Negative images of migrants and refugees are being created more and more often, most of the time omitting the benefits, e.g. those of an economic nature, resulting from influxes of people from other countries. ${ }^{9}$

Women and girls who migrate may suffer doubly from these attitudes, experiencing discrimination not only on the basis of their immigrant status, but also on the basis of their gender. Many migrant women experience various forms of discrimination and mistreatment - including sexual harassment - in the workplace, while searching for housing, using public transport, and using education and health services. Migrant women are therefore a group that is particularly exposed to many dangers arising from the fact of their being both migrants and women. ${ }^{10}$

6 Ibidem, p. 85.

7 Ibidem, p. 86.

8 Ibidem, p. 19.

9 International Migration, Racism, Discrimination and Xenophobia, International Labour Office (ILO) International Organization for Migration (IOM) Office of the United Nations High Commissioner for Human Rights (OHCHR), August 2001, p. 1, https://publications.iom.int/system/files/pdf/international_migration_racism. pdf (access 15.10.2020).

10 Five reasons migration is a feminist issue, „United Nations Population Fund”, https:// www.unfpa.org/news/five-reasons-migration-feminist-issue (access 20.10.2020). 
The subject of the analysis undertaken in this work is the specificity of women's migration, the problems faced by women who have voluntarily left or who were forced to leave their countries of origin, and an assessment of women's integration processes in Europe.

To study the issues presented in this article, a review of the available literature was used, as well as data available on the websites of the OECD and the Committee of the European Commission.

As women account for almost half of all migrants, data on migration should be gender-sensitive, and state policies must take into account how gender shapes the different needs of migrants. ${ }^{11}$

In this article, two issues have been taken into account as research questions: 1. are immigrant/refugee women treated the same as immigrant/ refugee men? and 2. is gender taken into account in the integration policies of European countries?

\section{Women's Migrations}

Women migrate for various reasons, but mostly due to problems in their countries of origin. The causes of women's migration include: poverty, a lack of development opportunities, opportunity inequality, gender inequalities and discrimination; conflict, violence, and political instability; socio-ethnic tensions and mismanagement; food scarcity, environmental degradation and climate change. ${ }^{12}$

Until the late 1970s, most papers on international migration focused directly on male migrants (usually seen as workers) and implicitly assumed that the majority of migrants were male. This assumption was especially dominant when attention was focused on the economic aspects of international migration, as it was widely believed that the participation of women in international labour migration was negligible. ${ }^{13}$

In research on migration in the 1960s and early 1970s, the expression "immigrants and their families" thus meant "male migrants and their wives and children." Women, if they migrated, were often unnoticed

${ }_{11}$ T. O'Neil, A. Fleury, M. Forest, Women on the move: migration, gender equality and the 2030 Agenda for Sustainable Development, https://www.odi.org/publications/10476women-move-migration-gender-equality-and-2030-agenda-sustainable-development (access 25.10.2020).

12 Women and migration, Introduction to Migration Guidance booklet \#6, p. 7, https://www.migrationyorkshire.org.uk/userfiles/attachments/pages/625/g-6-womenandmigration-iun-june-2015.pdf (access 28.10.2020).

${ }^{13} \mathrm{H}$. Zlotnik, The global dimensions of female migration, Migration Policy Institute, 1 March 2003, https://www.migrationpolicy.org/article/global-dimensions-femalemigration (access 28.10.2020). 
and perceived through the prism of their own passivity in the migration process and their place in the home. ${ }^{14}$

Research carried out in the 1970s and 1980s began to include women, but did not bring about a radical change in thinking about who the migrants were. One of the main questions about women during this period was whether migration "modernized" women, and whether it liberated them from their traditional values and behaviours. In the 1970s and 1980s neoclassical economic and push-pull demographic models, gender responsibilities were thought to explain why women were less likely than men to participate in migration decisions or in a host country's workforce when they joined their husbands. Statistics show that men still constitute the largest number of migrants, ${ }^{15}$ and the share of women in the total number of international migrants has recently decreased, from $49.3 \%$ in 2000 to $47.9 \%$ in 2019 . However, in 2019 , out of 272 million, as many as 130 million migrants were still women. ${ }^{16}$

The share of immigrant women also varied by region. Since 1990, the proportion of female migrants has increased in all regions except East Asia and the Pacific (EAP). In Europe and Central Asia (ECA), the share of female migrants slightly increased from $52 \%$ in 1990 to $52.4 \%$ in 2017. In South Asia, the percentage of women among international migrants increased during this period from $46.7 \%$ to $48.3 \%$. The growing proportion of women among all immigrant women in a country is determined not only by women moving to the country - this can be partly explained by the longer life expectancy of migrant women compared to men. Conversely, the share of female migrants in the EAP fell from $48.6 \%$ in 1990 to $41.7 \%$ in 2017.

The declining share of adult female migrants may reflect the increasing demand for migrant workers in male-dominated sectors in some parts of the region. When women do not have the same access to employment in certain occupations, this can affect the gender composition of international labour migration. ${ }^{17}$

${ }_{14}$ M. Boyd, E. Grieco, Women and Migration: Incorporating Gender into International Migration Theory, Migration Policy Institute, 1 March 2003, https://www.migrationpolicy.org/article/women-and-migration-incorporating-gender-internationalmigration-theory (access 28.10.2020).

15 Ibidem.

16 International Migration 2019, Department of Economic and Social Affairs, United Nations, https://www.un.org/development/desa/pd/sites/www.un.org.development.desa.pd/files/files/documents/2020/Feb/un_2019_internationalmigration_wallchart.pdf (access 30.10.2020).

17 E. Rubiano-Matulevich, K. Beegle, Women and migration: Exploring the data, https://blogs.worldbank.org/opendata/women-and-migration-exploring-data (access 28.10.2020). 
In 2019, the proportion of women among all international migrants was the highest in North America (51.8\%) and Europe (51.4\%). In Oceania (50.4\%), Latin America and the Caribbean (49.9\%), Central and South Asia (49.4\%) and East and South East Asia (49.3\%), the percentage of female and male migrants was almost equal. The lowest percentage of migrant women was in Sub-Saharan Africa (47.5\%) as well as North and West Africa and Asia (35.5\%). ${ }^{18}$

The significant number of migrant women is a consequence of social, economic, and political changes in the world. The feminisation of migration is a consequence of the growing awareness among women as well as their greater autonomy. ${ }^{19}$

The study of women's migration becomes an important problem and can be analysed in numerous aspects. It can even be seen that women are beginning to predominate in many migratory flows. There is an increasing number of situations where a woman migrates first, and then her husband and children follow her to a new country. In short-term migrations, on the other hand, women go to work in relatively close countries and send most of the money they earn back home, thanks to which they can significantly improve the living conditions of their entire families. ${ }^{20}$

\section{Women's Labour Migration}

Women's motivations and types of migration are changing. Nowadays, women migrate for many reasons, one of the most popular being the search for a job.

Z. Kawczyńska-Butrym draws attention to three groups of factors that encourage women to migrate for work:

1. the particularly difficult financial situations of women and their families,

2. employment-friendly specific offers from host countries,

3. so-called trips for oneself. ${ }^{21}$

Each woman can experience migration differently. According to Krystyna Slany, it can be an event that is:

18 International Migration 2019..., op.cit.

19 U. Walczak, Migracje Kobiet Integracja Międzykulturowa Polskich Kobiet z matżeństw mieszanych w Wielkiej Brytanii w Kontekście Stresu Akulturacyjnego, „Zoon Politikon", no. 9/2018, p. 73, DOI: 10.4467/2543408XZOP.18.014.10509.

${ }^{20}$ D. Praszałowicz, Polskie studia na temat migracji kobiet: wybrane perspektywy teoretyczne $i$ wyniki badań, in: Migracje kobiet. Pesrpektywa wielowymiarowa, ed. K. Slany, Cracow 2008, p. 51.

${ }^{21}$ Z. Kawczyńska-Butrym, Migracje. Wybrane zagadnienia, Lublin 2009, p. 39. 
- "wonderful, cognitive, revealing, especially towards oneself, reconstructing one's own identity;

- everyday, ordinary, resulting from the habit of migration;

- a strategy for getting daily bread;

- bringing confusion, fear, terror in the face of traumatic migratory experiences;

- raising concerns about the future, uncertainty of fate, lack of support;

- the greatest challenge in the face of having to support the family and very often being its sole breadwinner". ${ }^{22}$

It is worth noting, however, as stated by Izabela Koryś, that "A migrant woman may be an independent entity in the migration process or migrate as a family member. In both cases, this translates into her situation in the country of residence". ${ }^{23}$

For example, where there is a clear division of roles in the family, married women do not take up employment also in the host country and stay at home in order to perform the traditional roles of wife and mother, not having to deal with the realities of the new world. ${ }^{24}$

However, more and more women from traditional societies start to migrate on their own precisely because, in their country, they are subordinate to their husband or father. Migration can facilitate women's access to education and economic resources, as well as improve their independence and status. ${ }^{25}$

Moving to countries where they will enjoy the same rights as a migrant man, migrant women have theopportunity to make decisions for themselves and a chance for possible personal development. Even if the jobs they take are often below their qualifications, equality in a host country becomes an important factor attracting many female immigrants. ${ }^{26}$

In addition, even if they take up work below their qualifications, they still receive higher earnings in the host country than for work consistent with their qualifications in their home country. Immigrant women are,

22 K. Slany, Co to znaczy być migrantka??, in: Migracje kobiet. Pesrpektywa wielowymiarowa, ed. K. Slany, Cracow, 2008, pp. 10-11.

${ }^{23}$ I. Koryś, op.cit., p. 6.

${ }^{24}$ J. Fomina, Czy migracja ma pleć? Analiza dziatalności organizacji pozarzqdowych wspierających migrantów w Polsce, Warsaw 2012, p. 5.

${ }_{25}$ T. O'Neil, A. Fleury, M. Forest, Women on the move: migration, gender equality and the 2030 Agenda for Sustainable Development, https://www.odi.org/publications/10476women-move-migration-gender-equality-and-2030-agenda-sustainable-development (access 25.10.2020).

26 I. Szczygielska, Migracje zarobkowe kobiet $i$ ich wptyw na funkcjonowanie rodzin, Warsaw 2013, p. 126. 
therefore, a source of skills. However, the reality is that their potential is often not fully exploited. ${ }^{27}$

Migrant women tend to be better educated than male migrants. Between 2000 and 2010, the number of migrant women with a higher education in OECD countries increased by 7.6 million (88\%), while a parallel increase among male immigrants was 5.9 million $(64 \%){ }^{28}$

Women's migration is possible thanks to the changes taking place in host societies. There is a need to replace working women in their traditional roles where women want to pursue their careers and where it is possible due to the level of wealth and the structure of the labour market. Immigrants can fill this gap. As Krystyna Slany notes: "It is the army of the mobile, international proletariat going to work abroad that supports women from rich countries in their traditional functions, enables them to reconcile roles that most often contradict each other due to typical social expectations towards women". ${ }^{29}$

The majority of international migrants (74\%) are people of working age - between 20-64, as shown in Chart 1 . Both women and men are presented for comparison. It can be seen that migrant women of working age constitute almost as numerous a group as men of the same age.

However, as they perform simple, low-paid jobs below their qualifications in host countries, migrant women sometimes become second-class citizens, deprived of social security and stability. Those women very often undertake jobs that are considered the least attractive, i.e. in housekeeping, catering, but also in the erotic industry. Most of these jobs are characterised primarily by low wages, but also by difficult working conditions and a lack of social protection. ${ }^{30}$

The work performed by immigrant women is described as dangerous, dirty, and demanding. In addition, the lack of regulations on the status of migrant women in some countries, as well as irregular working hours, causes considerable difficulty not only in finding a better job, as mentioned above, but also in improving qualifications when equality programs are offered in a host country. ${ }^{31}$

27 Integration on migrant women, European Web Site On Integration, European Commission, https://ec.europa.eu/migrant-integration/feature/integration-of-migrant-women (access 28.10.2020).

28 A. King-Dejardin, The Social Construction Of Migrant Care Work At the intersection of care, migration and gender, Genewa 2019, p. 20.

${ }^{29}$ K. Slany, op.cit., p. 13.

${ }^{30}$ I. Szczygielska, op.cit., p. 127.

31 K. Slany, op.cit., p. 13. 


\section{Chart 1. Migrant men and women according to age}

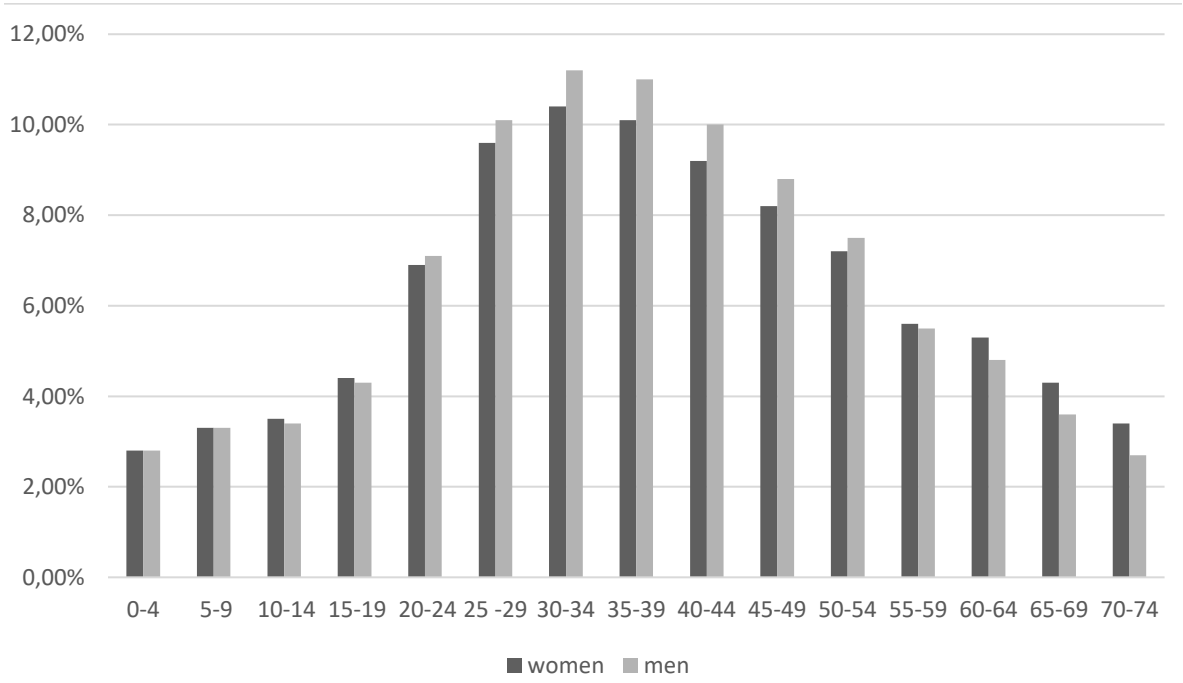

Source: World Migration Report 2020, https:/www.un.org/sites/un2.un.org/files/ wmr_2020.pdf, p. 22.

Migrant women undertaking housemaid jobs in a host country, which means living with the family they work for, have limited opportunities to find another, better paid job. It is also noteworthy that such work is often treated as insignificant and woman doing the work becomes "socially invisible". ${ }^{32}$

As Izabela Koryś notes, "It is difficult for female migrants to break out of the housekeeping sector. When applying for legal and stable jobs in the so-called primary labour market, they must compete not only with men but also with women from the host society". ${ }^{3}$

Although the proportion of migrant women with a tertiary education is similar to that of native women and male migrants, women born outside the EU are more likely to work below their qualifications and are also much less likely to be employed. The reasons for this also lie in the lack of diplomas confirming their real skills. ${ }^{34}$

32 Ibidem, p. 13.

${ }_{33}$ I. Koryś, op.cit., p. 3.

34 Integration on migrant women, European Web Site On Integration, European Commission, https://ec.europa.eu/migrant-integration/feature/integration-of-migrant-women (access 28.10.2020). 
Another important problem faced by women migrating for work is the lack of loved ones in everyday life. As Joanna Fomina rightly states, "Economic migrants who have left their families in their country of origin and earn their living by providing childcare and housekeeping services also experience the migration process in a specific way. Even if they can visit their family regularly (they have regular stay), they may experience psychological problems resulting from a sense of loss or remorse more often than male migrant workers". ${ }^{35}$

\section{Women Refugees}

By the end of 2018, there was a total of 25.9 million refugees worldwide. The total number of refugees is at its highest ever, although the annual growth rate has slowed since $2012 .{ }^{36}$

UNHCR defines refugees as persons who have "fled from war, violence, conflict or persecution and crossed an international border to find safety in another country", while asylum seekers are those who have submitted an application for international protection in an asylum country that has not yet been processed. ${ }^{37}$

Most refugees move to neighbouring low-and-middle-income countries, but it is estimated that $16 \%$ eventually move to high-income countries, including the United Kingdom (UK), Australia and Canada - countries that often differ greatly from their countries of origin in geographical and cultural terms.

In the years 2003-2018, according to the available data, the percentage of female refugees was relatively constant and oscillated between $47 \%$ and $49 \%$ of the global number of refugees.

Many migrant women, refugee women and asylum-seeking girls faced various forms of violence both in their countries of origin and while travelling, and sometimes even after arriving in a host country. This is also the case for women migrating to Europe. Many migrant women are of childbearing age, and they sometimes become pregnant and give birth during migration journeys or resettlement. Childbirth in the period of forced migration and early resettlement increases the vulnerability of refugees to numerous adverse effects for the mother and the newborn baby. One of them is postpartum depression (PPD). Studies show a 2-5 times

35 J. Fomina, op.cit., p. 3.

36 World Migration Report 2020, op.cit., pp. 2, 39.

37 United Nations High Commissioner for Refugees, What is a refugee? UNHCR, 2019, https://www.unhcr.org/what-is-a-refugee.html (access 15.12.2020). 
higher risk of PPD in refugee women displaced to high-income countries compared to non-immigrant women. ${ }^{38}$

Another problem refugee women encounter is that of finding a job. Recent OECD data shows that it takes longer for them to find a job in a new location than for adult male refugees. Refugee women who are employed often only work part-time. They also have a lower level of language skills in their host countries compared to men in the first two to three years after arrival, and often receive less integration support than men, both in terms of language training and active labour market measures. ${ }^{39}$

\section{The Integration of Immigrant Women in Europe}

The feminisation of migration made migrant women visible in European societies and an important part of them. However, it is worth noting that women's migrations are very diverse and often cannot be generalised. The nature of women's migration is very diverse and results from their diverse social positions and experiences. On the other hand, these migratory experiences result not only from them being women, but are also related to other factors, such as: social class, race or ethnicity, as well as the age or sexual orientation of migrant women. All these and other factors will have an impact on the causes and patterns of women's migration and on their experiences when they arrive in a new country. Moreover, their experiences are also shaped by the individual legislative and political regimes of the countries they leave, travel through, and those they eventually reach and want to reach. In view of all this diversity, it is a mistake to generalise about "migrant women", especially when it is assumed that they will integrated into a host country. Thus, migrant women/refugees who come to European countries constitute a heterogeneous group in many respects. This heterogeneity should be taken into account in integration processes. ${ }^{40}$

Women come to Europe for many different reasons. They can come as labour migrants - often filling gaps in the service sector, highly specialised workers, family members, or refugees. With the increasing diversity of the legal status and rights of migrant women, as highlighted in the opinion

${ }^{38}$ S. Haque, M. Malebranche, Impact of culture on refugee women's conceptualization and experience of postpartum depression in high-income countries of resettlement: A scoping review, DOI: https://doi.org/10.1371/journal.pone.0238109.

39 Integration on migrant women, European Web Site On Integration, European Commission, https:/ec.europa.eu/migrant-integration/feature/integration-of-migrant-women (access 28.10.2020).

40 J. Freedman, Women. Migration and Activism in Europe, "Amnis", no. 8/2008, DOI: https://doi.org/10.4000/amnis.604. 
of the European Economic and Social Committee on the inclusion of migrant women in the labour market, there are differences in the results of integration.

Where policies and support frameworks for women migrants exist, they are usually found in countries that have early adopted special introduction policies for newcomers. By focusing on language learning and social orientation courses, mainly for women arriving in the context of family migration, policymakers quickly recognised the need for targeted measures based on specific needs. ${ }^{41}$

On the other hand, Liav Orgad points out that the goal of integration should be to transfer a certain level of knowledge; citizens need to know something about their political community. The question arises whether newcomers should know only the basic laws and political institutions of society, or should they also know the basic social customs and cultural norms? What is the significance of the history, religious traditions or everyday life of refugee/immigrant host societies? ?2 $^{42}$

It is the interaction between immigrants and host societies, with their characteristics and reactions to newcomers, that determines the direction and timing of the integration process. However, it is the host societies, especially their institutional structures and responses to newcomers, that is much more important to the outcome of this process than the immigrants themselves. ${ }^{43}$

As Monika Banaś rightly states: "The generally understood integration policy towards immigrants consists of modelling the social reality in such a way that newcomers with a culturally, religious, or ethnically different experience and the host society can build relationships based on voluntary, unforced, harmonious cooperation, with the effective use of [one's] own potentials - knowledge, abilities, skills and life experience". ${ }^{44}$

The OECD publication "Making Integration Work - Family Migrants" of 2017 presents the difficulties faced by women in the integration processes. It focuses primarily on the labour market. The OECD emphasised the need to address the issue of women's social isolation and to introduce

${ }^{41}$ Integration on migrant women, European Web Site On Integration, European Commission, https://ec.europa.eu/migrant-integration/feature/integration-of-migrantwomen (access 28.10.2020).

${ }^{42}$ L. Orgad, The citizen-makers: Ethical dilemmas in immigrant integration, "European Law Journal", no. 6/2019, pp. 524-543.

${ }^{43}$ R. Penninx, Problems of and solutions for the study of immigrant integration, "Comparative Migration Studies", no. 7/2019, DOI: https://doi.org/10.1186/s40878-019-0122-x.

${ }_{44}$ M. Banaś, Wielość kultur, różnorodność tradycji, jedno społeczeństwo. Szwedzki model polityki integracyjnej, p. 1, https://www.uj.edu.pl/documents/3337228/64d5af4d167e-4f49-bf92-120135dlaldf (access 20.10.2020). 
measures to facilitate their social integration. It was pointed out that social integration is an important element that may facilitate integration in the labour market. Projects should support the social inclusion of women by establishing new social connections within the host society. A particularly valuable activity in the processes of women's integration is their participation in social and political life at the local level. Women participating in various local cultural and sports events or activities for the benefit of the local community can more easily get to know the culture of the host country and learn about various aid programs..$^{45}$

Activities at the local level may include language training as well as removing obstacles to labour market integration, such as helping to create an up-to-date resume, preparing for an interview, or providing access to childcare during work hours. ${ }^{46}$

Recent studies on the integration of refugees into the labour market justify the focus on economic issues. Therefore, the question arises as to whether obtaining employment by migrants will automatically strengthen social integration. It is probable that better social integration facilitates the job search on the one hand, and the new job of an immigrant may help in integration. ${ }^{47}$ Research shows that integration into the labour market is an important step on the way to social inclusion. Work, in addition to the economic aspect, also carries intangible assets, including a sense of belonging to society. ${ }^{48}$

However, all integration activities should also take into account the cultural diversity of immigrant women and their real needs. Furthermore, integration efforts definitely need to be more gender sensitive and analyse the determinants of gender differences in integration.

When host countries did pay attention to gender, it was usually a matter of facilitating women's migration to care work in order to fill employment gaps. ${ }^{49}$

45 Making integration work - family migrants, OECD Publishing, 2017, pp. 46-67, DOI: https://dx.doi.org/10.1787/9789264279520-en.

${ }^{46}$ Commission Implementing Decision of 6.11.2019, European Commision, Brussels, 6.11.2019, https://ec.europa.eu/home-affairs/sites/homeaffairs/files/financing/fundings/migration-asylum-borders/asylum-migration-integration-fund/union-actions/ docs/revised-amif-awp-2019.pdf (access 25.11. 2020).

${ }_{47}$ M. Barslund, A. Di Bartolomeo, L. Ludolph, Gender Inequality and Integration of Non-EU Migrants in the EU, CEPS Policy Insights, no. 6/2017, p. 5, http://aei.pitt. edu/84486/1/No_2017-06_MB_et_al_Gender_Inequality_and_Integration_of_NonEU_Migrants_in_the_EU.pdf (access 25.11.2020).

${ }_{48}$ N.C Morse, R.S. Weiss, The function and meaning of work and the job, „American Sociological Review", no. 2/2020, pp. 191-198.

49 J.L. Hennebry, A.J. Petrozziello, Closing the Gap? Gender and the Global Compacts for Migration and Refugees, „International Migration”, no. 6/2019, pp. 115-113. 
Political focus on the integration of immigrant women is still insufficient in many European Union Member States. A background paper from the European Court of Auditors indicated that many EU Member States lack immigrant policies. Out of 32 governments that responded (27 Member States, 4 Belgian regions, and Norway), only 7 have such a policy in place. The 2018 report of the European Fundamental Rights Agency (FRA) also confirmed that there is little evidence across the EU of action plans and strategies with a particular focus on migrant women or gender issues. ${ }^{50}$

In most countries, only minimal efforts are made to identify the problems with the integration of female immigrants into society, and key policy documents do not distinguish between men and women.

There are significant differences in the results of integrating male and female migrants in many EU countries. For example, in 2016, the difference between the employment rate of men and women born outside the EU was almost 20 percentage points, which is a much larger difference than that between men and women born in host countries (14.5 percentage points). ${ }^{51}$

The gap, in terms of employment and labour force participation, is particularly striking between male and female migrants from third countries. $^{52}$

In some cases it may be related to their social isolation, which does not facilitate learning a host country's language and culture or building relationships with members of the host community, thus becoming an obstacle to their social integration..$^{53}$

For this reason, the Council of Europe has focused its attention on the need to take measures to ensure that migrant women, refugees, and asylum seekers have access to their human and social rights in terms of

${ }^{50}$ Commission Implementing Decision of 6.11.2019, European Commision, Brussels, 6.11.2019, https://ec.europa.eu/home-affairs/sites/homeaffairs/files/financing/ fundings/migration-asylum-borders/asylum-migration-integration-fund/unionactions/docs/revised-amif-awp-2019.pdf (access 25.11.2020).

51 Commission Implementing Decision of 6.11.2019, European Commission, Brussels, 6.11.2019, https://ec.europa.eu/home-affairs/sites/homeaffairs/files/financing/fundings/migration-asylum-borders/asylum-migration-integration-fund/unionactions/docs/revised-amif-awp-2019.pdf (access 25.11.2020).

52 M. Barslund, A. Di Bartolomeo, L. Ludolph, Gender Inequality and Integration of Non-EU Migrants in the EU, http://aei.pitt.edu/84486/1/No_2017-06_MB_et_al_ Gender_Inequality_and_Integration_of_Non-EU_Migrants_in_the_EU.p. $d f$ (access 25.11.2020).

53 Commission Implementing Decision of 6.11.2019, European Commission, Brussels, 6.11.2019, https:/ec.europa.eu/home-affairs/sites/homeaffairs/files/financing/fundings/migration-asylum-borders/asylum-migration-integration-fund/unionactions/docs/revised-amif-awp-2019.pdf (access 25.11.2020). 
personal freedom, employment, housing, health, education, protection, social and welfare services, as appropriate. This also includes access to information about their rights and available services. As can be read on the official website, "The Council of Europe and other international instruments should serve as a blueprint for all efforts and measures taken by Member States to protect the human rights of migrant, refugee and asylum-seeking women and girls". ${ }^{54}$

Integration efforts need to be more gender sensitive and analyse more closely the determinants of gender differences in integration. Integration activities should also take into account the cultural diversity of immigrant women and their real needs, along with any difficulties resulting from this diversity. ${ }^{55}$

Several problems can be distinguished that hinder the integration of women in a new environment. The first is the lack of language skills, which very often prevents real participation in social relations and promotes social isolation.

In addition, a lack of the language skills limits the access of immigrants to, among other things, knowledge about their own rights, organisations protecting women's rights, and even language courses. The position of immigrant women in the family and their responsibilities related to work at home and caring for children very often have an impact on the limited access of immigrant women to the labour market as well as to integration itself.

The European Social Fund has financed many projects aimed at integrating immigrant women into the labour market, such as: the German project "Strong at Work - Mothers from a Migrant Background Enter the Labour Market", which provides professional orientation and individual support to mothers from migrant backgrounds, the Swedish Mirjam project, which provides career guidance and inspiration for newly arrived refugees, the Irish project "Building Better Futures", aimed at supporting migrant women who face additional barriers to entrepreneurship, or the Slovenian project "Razkirte roke 3", which brings together migrant women to start a business while improving their language skills. ${ }^{56}$

${ }_{54}$ Migrant and refugee women and girls, Council of Europe, https://www.coe.int/en/ web/genderequality/migrant-and-refugee-women-and-girls (access 26.11.2020).

55 G. Agatiello, L. Humer, Eurodiaconia's Guidelines for the Integration of Migrant Women, Brussel 2018, 7, https:/www.eurodiaconia.org/wordpress/wp-content/ uploads/2018/12/Eurodiaconia_Guidelines_Integration_Migrant_Women_WEB.pdf (access 26.11.2020).

56 Integration on migrant women, European Web Site On Integration, European Commission, https://ec.europa.eu/migrant-integration/feature/integration-of-migrant-women (access 26.10.2020). 
However, these projects are only a drop in the ocean of needs in women's integration processes.

\section{Conclusions}

Migrant women and refugee women face various inequalities in the form of discriminatory practices that prevent them from full and equal participation in all aspects of social, political, and economic life. In addition, women face a gender-related risk of exploitation and abuse during migration, poorer working conditions, pay inequality, low levels of social protection, and barriers to accessing labour and human rights in a host country. Gender also influences the trajectories, rates, and levels of migration, as well as remittance flows and their use. ${ }^{57}$

Although little attention has been paid in many countries to the integration of migrant women at the level of state policies, the number of initiatives aimed at undertaking deliberate efforts in this area is increasing. Activities for the integration of women focus on three areas: 1) social inclusion, 2) discrimination and access to rights, and 3) integration in the labour market. ${ }^{58}$

Successful integration is important for a number of reasons, with the economic one being of crucial importance, meaning that the less successful integration of newcomers into the labour market, the greater the burden on public budgets.

A homogeneous approach to integration processes without listening to real needs and the lack of understanding of different value systems becomes one of the most important reasons for the formation of integration barriers.

Activities for the integration of women should cover various areas and equip immigrant women/refugees with such skills and competences so that integration can take place at various levels and in various spheres. Integration programs should take into account cultural, ethnic, and religious diversity, while also recognising gender differences.

\section{References}

Agatiello G.L., Humer Eurodiaconia's Guidelines for the Integration of Migrant Women, Brussel 2018, https://www.eurodiaconia.org/wordpress/

57 J.L. Hennebry, A.J. Petrozziello, op.cit., pp. 115-138.

${ }_{58} \mathrm{H}$. Bojar, Wzory imigracji z perspektywy rodziny $i$ ich potencjat integracyjny w kontekście polskim, Institute of Public Affairs, Warsaw 2011, p. 5, https://www.isp.org.pl/ uploads/drive/oldfiles/H.BojarWzoryimigracjizperspektywyrodzinyiichpotencjaintegracyjnywkontekciepolskim.pdf (access 27.11.2020). 
wp-ntent/uploads/2018/12/Eurodiaconia_Guidelines_Integration_ Migrant_Women_WEB.pdf (access 26.10.2020).

Banaś M., Wielość kultur, różnorodność tradycji, jedno społeczeństwo. Szwedzki model polityki integracyjnej, https://www.uj.edu.pl/documents/3337228/64d5af4d-167e-4f49-bf92120135dlaldf (access 20.10.2020).

Barslund M.A., Di Bartolomeo L., Gender Inequality and Integration of Non-EU Migrants in the EU, CEPS Policy Insights, no. 6/2017, http://aei.pitt.edu/84486/1/No_2017-06_MB_et_al_Gender Inequality_and_Integration_of_Non-EU_Migrants_in_the_EU.pdf (access 25.11.2020).

Bojar H., Wzory imigracji z perspektywy rodziny $i$ ich potencjat integracyjny w kontekście polskim, Institute of Public Affairs, Warsaw 2011, https:// www.isp.org.pl/uploads/drive/oldfiles/H.BojarWzoryimigracjizp erspektywyrodzinyiichpotencjaintegracyjnywkontekciepolskim.pdf (access 27.11.2020).

Boyd M., Grieco E., Women and Migration: Incorporating Gender into International Migration Theory, Migration Policy Institute, 1 March 2003, https://www.migrationpolicy.org/article/women-and-migrationincorporating-gender-international-migration-theory (access 28.10.2020).

Commission Implementing Decision of 6.11.2019, European Commision, Brussels, 6.11.2019, https://ec.europa.eu/home-affairs/sites/homeaffa irs/files/financing/fundings/migration-asylum-borders/asylummigration-integration-fund/union-actions/docs/revised-amif-awp2019.pdf (access 25.11.2020).

Five reasons migration is a feminist issue, United Nations Population Fund, https://www.unfpa.org/news/five-reasons-migration-feminist-issue (access 20.10.2020).

Fomina J., Czy migracja ma pteć? Analiza dziatalności organizacji pozarzadowych wspierajacych migrantów w Polsce, The Institute of Public Affairs, Warsaw 2012.

Freedman J., Women, Migration and Activism in Europe, „Amnis”, no. 8/2008, DOI: https://doi.org/10.4000/amnis.604.

Gacek M., Strategie migracyjne Polaków po 2004 roku. Przypadek Szkocji, „Pogranicze. Polish Borderlands Studies”, no. 1/2013.

Haque S., Malebranche M., Impact of culture on refugee women's conceptualization and experience of postpartum depression in high-income countries of resettlement: A scoping review, DOI: https://doi.org/10.1371/ journal.pone.0238109.

Hennebry J.L., Petrozziello A., Closing the Gap? Gender and the Global Compacts for Migration and Refugees, „International Migration”, no. 6/2019. 
Integration on migrant women, European Web Site On Integration, European Commission, https://ec.europa.eu/migrant-integration/feature/integra tion-of-migrant-women (access 28.10.2020).

International Migration 2019, Department of Economic and Social Affairs, United Nations, https://www.un.org/development/desa/pd/sites/www. un.org.development.desa.pd/files/files/documents/2020/Feb/un_2019_ internationalmigration_wallchart.pdf (access 20.10.2020).

International Migration, Racism, Discrimination and Xenophobia, International Labour Office (ILO) International Organization for Migration (IOM) Office of the United Nations High Commissioner for Human Rights (OHCHR), August 2001, https://publications. iom.int/system/files/pdf/international_migration_racism.pdf (access 15.10.2020).

Kawczyńska-Butrym Z., Migracje. Wybrane zagadnienia, University of Maria Skłodowska Curie Press, Lublin 2009.

King-Dejardin A., The Social Construction of Migrant Care Work At the intersection of care, migration and gender, International Labour Office, Genewa 2019.

Koryś I., Kobiety migrantki: warunki udanej integracji, The Institute of Public Affairs, Warsaw 2009.

Making integration work - family migrants, OECD Publishing, 2017, DOI: https://dx.doi.org/10.1787/9789264279520-en.

Migrant and refugee women and girls, Council of Europe, https://www.coe. int/en/web/gen derequality/migrant-and-refugee-women-and-girls (access 26.11.2020).

Morse N.C., Weiss R.S., The function and meaning of work and the job, „American Sociological Review”, no. 2/1955.

O'Neil T., Fleury A., Forest M., Women on the move: migration, gender equality and the 2030 Agenda for Sustainable Development, https://www. odi.org/publications/10476-women-move-migration-gender-equalityand-2030-agenda-sustainable-development (access 25.10.2020).

Orgad L., The citizen-makers: Ethical dilemmas in immigrant integration, „European Law Journal”, no. 6/2019.

Penninx R., Problems of and solutions for the study of immigrant integration, „Comparative Migration Studies”, no. 7/2019, DOI: https://doi. org/10.1186/s40878-019-0122-x.

Praszałowicz D., Polskie studia na temat migracji kobiet: wybrane perspektywy teoretyczne i wyniki badań in Migracje kobiet. Perspektywa wielowymiarowa, ed. K. Slany, Jagiellonian University Press, Cracow 2008.

Rubiano-Matulevich E., Beegle K., Women and migration: Exploring the data, https://blogs.worldbank.org/opendata/women-and-migrationexploring-data (access 10.11.2020). 
Slany K., Co to znaczy być migrantka? in: Migracje kobiet. Perspektywa wielowymiarowa, ed. K. Slany, Jagiellonian University Press, Cracow 2008.

Szczygielska I., Migracje zarobkowe kobiet $i$ ich wptyw na funkcjonowanie rodzin, Warsaw University Press, Warsaw 2013.

United Nations High Commissioner for Refugees, What is a refugee?, UNHCR, 2019, https://www.unhcr.org/what-is-a-refugee.html (access 15.11.2020).

Walczak U., Migracje kobiet. Integracja międzykulturowa polskich kobiet $z$ matżeństw mieszanych w Wielkiej Brytanii w kontekście stresu akulturacyjnego, „Zoon Politikon”, no. 9/2018, DOI: 10.4467/2543/408 XZOP.18.014.10509.

Women and migration, Introduction to Migration, Guidance booklet no. 6, https://www.migrationyorkshire.org.uk/userfiles/attachments/ pages/625/g-6-womenandmigration-iun-june-2015.pdf (access 28.10.2020).

World Migration Report 2020, https://www.un.org/sites/un2.un.org/files/ wmr_2020.pdf (access 20.11.2020).

Zlotnik H., The global dimensions of female migration, Migration Policy Institute, 1 March 2003, 2020, https://www.migrationpolicy.org/article/ global-dimensions-female-migration (access 28.10.2020). 